\title{
Studi tentang penilaian autentik pada pembelajaran berbasis proyek materi optika geometri kelas X di SMAN 4 Malang
}

\author{
Dheka Januarifin, Lia Yuliati*, Sumarjono \\ Universitas Negeri Malang, Jl. Semarang No. 5 Malang, Jawa Timur, Indonesia \\ *Penulis korespondensi, Surel: lia.yuliati.fmipa@um.ac.id
}

Paper received: 01-07-2021; revised: 15-07-2021; accepted: 31-07-2021

\begin{abstract}
Abstrak
Penelitian ini bertujuan untuk mendeskripsikan hasil belajar siswa pada penilaian autentik pada pembelajaran berbasis proyek dan implementasi penilaian autentik pada pembelajaran berbasis proyek materi optika geometri kelas X SMAN 4 Malang. Pengumpulan data dilakukan dengan teknik observasi dan wawancara. Data proses penilaian sikap, proses penilaian proyek, proses penilaian produk, nilai sikap, nilai tugas proyek dan nilai produk dianalisis secara kuantitatif. Data hasil wawancara dianalisis secara kualitatif. Hasil penelitian menunjukkan keterlaksanaan penilaian autentik pada pembelajaran berbasis proyek terlaksana dengan sangat baik. Hasil belajar siswa pada ranah afektif mengalami penurunan pada pertemuan kedua dan mengalami kenaikan pada pertemuan ketiga dan keempat. Hasil belajar siswa pada ranah kognitif dan psikomotor berupa kemampuan menghasilkan produk, dapat menyusun laporan proyek, membangun sendiri pengetahuan dan dapat menerapkan pengetahuan dalam kehidupan nyata.
\end{abstract}

Kata kunci: penilaian autentik; pembelajaran berbasis proyek; optika geometri

\section{Pendahuluan}

Fisika merupakan ilmu yang mempelajari tingkah laku alam dalam berbagai bentuk gejala untuk dapat memahami apa yang mengendalikan atau menentukan tingkah laku tersebut. Murdilarto (2013) menjelaskan bahwa Fisika merupakan ilmu yang berusaha memahami aturan-aturan alam yang begitu indah dan dengan rapi dapat dideskripsikan secara matematis. Untuk dapat menguasai konsep-konsep fisika tersebut diperlukan kerja sama antar komponen pembelajaran. Salah satu komponen penting dalam pembelajaran adalah model pembelajaran. Salah satu contoh model pembelajaran yang disaranakan dalam kurikulum 2013 adalah pembelajaran berbasis proyek.

Menurut Istarani (2011), Belajar berbasis proyek (project-based learning) adalah sebuah model pembelajaran yang inovatif, yang menekankan belajar kontekstual melalui kegiatan-kegiatan yang kompleks. Model pembelajaran berbasis proyek merupakan pembelajaran yang dapat meningkatkan kreativitas dan memotivasi siswa lebih aktif dalam menulis. Dalam pembelajaran berbasis proyek, guru atau instruktur tidak lebih aktif dan melatih secara langsung, akan tetapi instruktur menjadi pendamping, fasilitator, dan memahami pikiran belajar (Ngalimun, 2012).

Dari hasil wawancara terhadap guru fisika SMA 4 Malang menunjukkan bahwa penilaian autentik sudah diterapkan dalam kegiatan pembelajaran namun pelaksanaannya masih kurang maksimal. Guru menerapakan penilaian autentik hanya sebatas pamahamannya, guru masih kesulitan menerapkan penilaian autentik dan kesulitan dalam mendeskrispsikan hasil penilaian autentik. Contoh kesulitan yang dialami guru adalah menilai siswa yang berjumlah banyak, memantau perkembangan siswa dan mendeskripsikan hasil penilaian autentik. Dari fakta yang terjadi di lapangan perlu adanya penjelasan lebih lanjut mengenai bagaimana penilaian autentik dilakukan dalam proses pembelajaran, 
terutama pada proses pembelajaran yang sesuai dengan kurikulum 2013 yaitu dengan pendekatan ilmiah.

Hasil persentase penguasaan materi soal fisika UN SMA/MA 2012/2013 menunjukkan bahwa materi optika geometri mendapat persentase 59.55\%. Persentase tersebut masih dibawah persentase provinsi yaitu $63.85 \%$.

Untuk mengatasi hal tersebut diperlukan referensi tentang penilaian autentik pada pembelajaran berbasisi proyek pada materi optika geometri. Referensi mengenai penilaian autentik pada ranah afektif, kognitif dan psikomotor. Wawancara untuk mengetahui respon siswa terhadap penilaian autentik pada pembelajaran berbasis proyek materi optika geometri kelas X SMA.

\section{Metode}

Penelitian ini merupakan penelitian deskriptif. Penelitian ini bertujuan untuk mendeskripsikan penilaian yang terjadi dalam pembelajaran secara apa adanya melalui pengumpulan data. Data-data tersebut dipaparkan dalam bentuk kalimat. Data penelitian berupa proses penilaian sikap, proses penilaian proyek, proses penilaian produk, nilai sikap, nilai tugas proyek, nilai produk, dan respon siswa terhadap penilaian autentik. Sumber data berasal dari hasil observasi terhadap siswa kelas X MIA V SMAN 4 Malang, proses penilaian autentik yang dilakukan oleh guru dan tugas proyek yang dikerjakan siswa. Pengumpulan data diperoleh dari observasi dan wawancara. Kegiatan analisis kuantitatif untuk data proses penilaian sikap, proses penilaian proyek, proses penilaian produk, nilai sikap, nilai tugas proyek dan nilai produk. Analisis kualitatif untuk data hasil wawancara.

\subsection{Instrumen Penelitian}

Untuk mendukung keterlaksanaan penelitian ini maka, digunakan instrumen penelitian berupa lembar observasi proses penilaian sikap, lembar observasi proses penilaian proyek, lembar observasi proses penilaian produk, rubrik penilaian sikap, rubrik penilaian proyek, rubrik penilaian produk, dan panduan wawancara.

\subsection{Pengumpulan Data}

Data yang diperoleh dari hasil obeservasi adalah proses penilaian sikap, proses penilaian proyek, proses penilaian produk, nilai sikap, nilai proyek dan nilai produk siswa pada proses kegiatan pembelajaran berbasis proyek materi optika di SMAN 4 Malang. Teknik ini digunakan untuk mengetahui penilaian autentik pada pembelajaran berbasis proyek. Diharapkan dari hasil observasi dapat dikumpulkan data-data yang mendukung proses penelitian. Wawancara digunakan untuk mengumpulkan data respon siswa terhadap penilaian autentik pada pembelajaran berbasis proyek materi optika geometri.

\subsection{Analisis Data}

Analisis dimulai dengan melakukan observasi mendalam terhadap siswa mengenai sikap siswa, kemampuan siswa dalam melaksanakan tugas proyek dan kamampuan siswa dalam menghasilkan produk. Data yang berupa sikap siswa, kemampuan siswa dalam melaksanakan tugas proyek dan kemampuan siswa dalam menghasilkan produk dianalisis sebagai berikut. 


\subsubsection{Kuantitatif}

Data yang berupa sikap, kemampuan siswa dalam melaksanakan tugas proyek dan kemampuan menghasilkan produk diberi skor untuk setiap indikator. Kemudian menjumlahakan skor yang diperoleh siswa. Untuk menentukan nilai siswa digunakan rumus :

$$
\mathrm{N}=\frac{\text { Skor yang diperoleh }}{\text { Skor maksimum }} \times 4
$$

Keterangan :

N = Nilai Akhir Siswa

Diperoleh kriteria sebagai berikut :

Tabel 3.1 Kriteria Nilai pada Kurikulum 2014

\begin{tabular}{|c|c|c|c|c|c|}
\hline \multicolumn{2}{|l|}{ Sikap } & \multicolumn{2}{|c|}{ Pengetahuan } & \multicolumn{2}{|c|}{ Keterampilan } \\
\hline Modus & Predikat & Skor rerata & Huruf & $\begin{array}{l}\text { Capaian } \\
\text { Optimum }\end{array}$ & Huruf \\
\hline \multirow{2}{*}{4,00} & \multirow{2}{*}{$\begin{array}{l}\text { SB } \\
\text { (Sagat Baik) }\end{array}$} & $3,85-4,00$ & A & $3,85-4,00$ & $\mathrm{~A}$ \\
\hline & & $3,51-3,84$ & A- & $3,51-3,84$ & A- \\
\hline \multirow{3}{*}{3,00} & \multirow{3}{*}{$\begin{array}{l}\text { B } \\
\text { (Baik) }\end{array}$} & $3,18-3,50$ & $\mathrm{~B}+$ & $3,18-3,50$ & $\mathrm{~B}+$ \\
\hline & & $2,85-3,17$ & $\mathrm{~B}$ & $3,85-3,17$ & $\mathrm{~B}$ \\
\hline & & $2,51-2,84$ & B- & $2,51-2,84$ & B- \\
\hline \multirow{3}{*}{2,00} & \multirow{3}{*}{$\begin{array}{l}\text { C } \\
\text { (Cukup) }\end{array}$} & $2,18-2,50$ & $\mathrm{C}+$ & $2,18-2,50$ & $\mathrm{C}+$ \\
\hline & & $1,85-2,17$ & $\mathrm{C}$ & $1,85-2,17$ & $\mathrm{C}$ \\
\hline & & $1,51-1,84$ & $\mathrm{C}-$ & $1,51-1,84$ & $\mathrm{C}-$ \\
\hline \multirow{2}{*}{1,00} & \multirow{2}{*}{$\begin{array}{l}\text { K } \\
\text { (Kurang) }\end{array}$} & $1,18-1,50$ & $\mathrm{D}+$ & $1,18-1,50$ & $\mathrm{D}+$ \\
\hline & & $1,00-1,17$ & $\mathrm{D}$ & $1,00-1,17$ & $\mathrm{D}$ \\
\hline
\end{tabular}

Sumber : Kemendikbud 2014

Data yang berupa proses penilaian sikap, proses penilaian proyek dan proses penilain produk dianalisis sebagai berikut:

2.3.1.1.Melakukan pengamatan terhadap proses penilaian autentik yang dilakukan oleh guru.

2.3.1.2.Melakukan pencatatan didalam lembar observasi proses penilaian autentik yang dilakukan guru.

2.3.1.3. Menentukan tingkat capaian dalam proses penilaian autentik oleh guru dengan menggunakan rumus:

Nilai Akhir $=\frac{\text { Skor } \text { Perolehan }}{\text { Skor Maksimal }} \times 100 \%$

Keterangan :

85-100 : Sangat Baik

70-84 : Baik 


$$
\begin{array}{ll}
51-69 & \text { : Cukup } \\
\leq 50 & \text { : Kurang }
\end{array}
$$

2.3.1.4.Menarik kesimpulan terhadap proses penilaian autentik yang dilakukan oleh guru.

\subsubsection{Kualitatif}

Analisis data yang selanjutnya adalah melakukan wawancara mendalam terhadap siswa kelas X MIA V. Setelah melakukan wawancara, dibuat salinan hasil wawancara dengan cara memutar kembali rekaman wawancara kemudian menuliskan kata - kata yang sesuai dengan hasil yang ada direkaman tersebut. Setelah ditulis hasil wawancara ke dalam salinan, selanjutnya dibuat reduksi data dengan cara abstraksi, yaitu mengambil data yang sesuai dengan konteks penelitian dan mengabaikan data yang tidak diperlukan. Data yang diambil adalah respon siswa yang berupa semangat dalam belajar, tanggung jawab, kerja sama, dapat memecahakan masalah, disiplin dah hati-hati.

\section{Hasil dan Pembahasan}

\subsection{Hasil}

Data penelitian ini diperoleh dari observasi dan wawancara yang dilakukan selama empat pertemuan. Diperoleh data nilai sikap, nilai proyek, nilai produk, proses penilaian sikap, proses penilaian proyek, proses penilaian produk dan hasil wawancara yang berupa respon siswa terhadap penilaian autentik pada pembelajaran berbasis proyek materi optika geometri.

\subsubsection{Nilai Sikap}

Dari data rata-rata nilai sikap selama empat pertemuan pada materi optika geometri dapat dilihat pada tabel 1.

Tabel 1 Nilai rata-rata untuk nilai sikap siswa selama empat pertemuan

\begin{tabular}{ll}
\hline Sikap siswa & Nilai rata-rata \\
\hline Pertemuan Pertama & 3.75 \\
Pertemuan Kedua & 3.59 \\
Pertemuan Ketiga & 3.69 \\
Pertemuan Keempat & 3.81 \\
\hline
\end{tabular}

\subsubsection{Nilai Proyek}

Selain data nilai sikap ada pula nilai tugas proyek siswa selama materi optika geometri dapat dilihat pada Tabel 2.

Tabel 2 Nilai rata-rata untuk tugas proyek selama materi optika geometri

\begin{tabular}{ll}
\hline Aspek yang dinilai & Nilai rata-rata \\
\hline Tugas produk & 3.66 \\
\hline
\end{tabular}


Berdasarkan Tabel 2 dapat dilihat bahwa nilai rata-rata tugas proyek selama materi optika geometri sudah sangat baik yaitu 3.66. Nilai tersebut didapat dari rubrik penilaian proyek. Rubrik tersebut terbagi atas tiga tahap yaitu perencanaan, pelaksanaan dan pelaporan.

\subsubsection{Nilai Produk}

Selain data nilai tugas proyek ada pula nilai tugas produk siswa selama materi optika geometri dapat dilihat pada Tabel 3.

Tabel 3 Nilai rata-rata untuk tugas produk selama materi optika geometri

\begin{tabular}{ll}
\hline Aspek yang dinilai & Nilai rata-rata \\
\hline Tugas produk & 3.50 \\
\hline
\end{tabular}

Berdasarkan Tabel 3 dapat dilihat bahwa nilai rata-rata tugas produk selama materi optika geometri sudah sangat baik yaitu 3.50. Nilai tersebut didapat dari rubrik penilaian produk. Rubrik tersebut terbagi atas tiga tahap yaitu perencanaan, proses dan hasil produk.

\subsubsection{Proses Penilain Sikap}

Selain diperoleh data nilai sikap, nilai proyek dan nilai produk, juga diperoleh data proses penilaian sikap, proses penilaian proyek dan proses penilaian produk. Dari hasil observasi yang telah dilakukan menggunakan lembar observasi terhadap proses penilaian sikap siswa selama pembelajaran berbasis proyek didapatkan data sesuai dengan Tabel 4 .

Tabel 4 Hasil Observasi terhadap Proses Penilaian Sikap Siswa

\begin{tabular}{l|l|l|l|l}
\hline \multirow{2}{*}{ Aspek } & \multicolumn{4}{|l}{ Pertemuan } \\
\cline { 2 - 5 } & $\mathbf{1}$ & $\mathbf{2}$ & $\mathbf{3}$ & $\mathbf{4}$ \\
\hline Persentase (\%) & $60 \%$ & $70 \%$ & $90 \%$ & $90 \%$ \\
\hline Kualifikasi & Cukup & Baik & Sangat Baik & Sangat Baik \\
\hline
\end{tabular}

Dari Tabel 4 dapat dilihat bahwa keterlaksanaan guru dalam menilai sikap siswa untuk empat pertemuan mengalami perubahan sebagai berikut: (1) pada pertemuan pertama aspek yang dilakukan guru adalah 6, yang mencapai persentase $60 \%$ dengan kategori cukup, (2) untuk pertemuan kedua aspek yang dilakukan guru naik menjadi 7 , yang mencapai persentase $70 \%$ dengan kategori baik, (3) untuk pertemuan ketiga aspek yang dilakukan guru adalah 9, yang mencapai persentase 90\% dengan kategori sangat baik dan (4) untuk pertemuan keempat aspek yang dilakukan guru adalah 9, yang mencapi persentase $90 \%$ dengan kategori sangat baik. Dapat diamati bahwa keterlaksanaan proses penilaian sikap yang dilakukan oleh guru semakin mengalami kenaikkan dalam setiap pertemuan.

Selain data proses penilaian sikap juga diperoleh data proses penilaian proyek pada pembelajaran fisika model pembelajaran berbasis proyek pada 
materi optika geometri. Dari hasil observasi yang telah dilakukan menggunakan lembar observasi terhadap proses penilaian proyek siswa selama pembelajaran berbasis proyek didapatkan data sesuai dengan Tabel 5 .

Tabel 5 Hasil Observasi terhadap Proses Penilaian Proyek

\begin{tabular}{l|l}
\hline Aspek & Skor \\
\hline Persentase (\%) & $90 \%$ \\
\hline Kualifikasi & Sangat baik \\
\hline
\end{tabular}

Dari Tabel 5 dapat dilihat keterlaksanaan guru dalam menilai tugas proyek selama materi optika geometri muncul 9 aspek. Mencapai persentase 90\% dengan kategori sangat baik. Aspek yang tidak muncul pada penilaian proyek adalah guru memantau kamajuan tugas proyek. Penilaian proyek dilaksanakan selama materi optika geometri.

Selain data proses penilaian proyek juga diperoleh data proses penilaian produk pada pembelajaran fisika model pembelajaran berbasis proyek pada materi optika geometri. Dari hasil observasi yang telah dilakukan menggunakan lembar observasi terhadap proses penilaian produk siswa selama pembelajaran berbasis proyek didapatkan data sesuai dengan Tabel 6 .

Tabel 6 Hasil Observasi terhadap Proses Penilaian Produk

\begin{tabular}{l|l}
\hline Aspek & Skor \\
\hline Persentase (\%) & $90 \%$ \\
\hline Kualifikasi & Sangat baik \\
\hline
\end{tabular}

Dari Tabel 6 dapat dilihat keterlaksanaan guru dalam menilai tugas produk selama materi optika geometri muncul 9 aspek. Mencapai persentase 90\% dengan kategori sangat baik. Aspek yang tidak muncul pada penilaian produk adalah guru memantau kamajuan hasil produk. Penilaian produk dilaksanakan selama materi optika geometri.

\subsubsection{Respon Siswa}

Respon siswa terhadap penilaian autentik pada pembelajaran berbasis proyek materi optika geometri diperoleh dari kegiatan wawancara. Wawancara dilaksanakan pada hari Rabu, 8 April 2015 setelah kegiatan pembelajaran fisika. Kegiatan wawancara dilaksanakan pada siswa yang telah menjalani kegiatan pembelajaran berbasis proyek. Diharapkan siswa dapat menyampaikan respon tentang pelaksanaan penilaian autentik.

Wawancara tidak hanya mengarah pada suka atau tidak suka terhadap pelaksanaan penilaian autentik, namun pada respon yang ditunjukkan dalam penilian autentik. Respon tersebut adalah kedisiplinan, keaktifan, kerja sama, tanggung jawab dan dapat mengatur waktu. Dari hasil wawancara tersebut diharapkan dapat digunakan sebagai dasar evaluasi kegiatan pembelajaran. 


\subsection{PEMBAHASAN}

\subsubsection{Hasil Belajar Siswa}

Hasil belajar tampak sebagai terjadi perubahan tingkah laku pada diri siswa yang dapat diamati dan diukur dalam bentuk perubahan pengetahuan, sikap dan keterampilan. Perubahan tersebut dapat diartikan terjadinya peningkatan dan pengembangan yang lebih baik dibandingkan dengan sebelumnya, misalnya dari tidak tahu menjadi tahu, sikap kurang sopan menjadi sopan dan sebagainya (Hamalik, 2007: 155)

Kenaikan dan penurunan nilai sikap siswa terjadi selama materi optika geometri. Penurunan nilai sikap tejadi pada pertemuan kedua. Hal ini terjadi karena pada pertemuan pertama adalah merancang teleskop sederhana. Kegiatan ini adalah kegiatan baru bagi siswa sehingga bisa menjadi variasi kegiatan pembelajaran. Siswa menjadi lebih nyaman dan aktif dalam merancang teleskop sederhana. Pada pertemuan kedua kegiatannya mirip dan cenderung sama dengan kegiatan pertama, yaitu konsultasi rancangan teleskop sederhana. Kegiatan yang cenderung sama membuat siswa bosan sehingga nilai sikap pada pertemuan kedua mengalami penurunan yang sangat drastis dari nilai rata-rata 3.75 menjadi 3.59 pada pertemuan kedua.

Kenaikan nilai sikap siswa terjadi pada pertemuan ketiga dan keempat. Pada pertemuan ketiga kegiatannya adalah membuat teleskop sederhana. siswa sangat antusias dan bersemangat dalam membuat teleskop sederhana. Selain dikerjakan diluar jam sekolah, lokasi pembuatan juga dilaksanakan diluar sekolah yaitu di kampus Universitas Negeri Malang. Hal ini meningkatkan daya tarik dan semangat siswa dalam membuat teleskop sederhana. Pada pertemuan keempat juga terjadi kenaikan nilai sikap siswa. Kegiatan pada pertemuan keempat adalah diskusi kelompok, mengumpulkan teleskop sederhana dan laporan proyek. Siswa sangat aktif dan bersemangat karena hasil karya mereka akan dinilai. Siswa sudah mulai tebiasa dengan kegiatan pada pembelajaran berbasis proyek, sehingga pada pertemuan keempat nilai sikap siswa mengalami kenaikan dari 3.69 pada pertemuan ketiga menjadi 3.81 pada pertemuan keempat. Dari uraian di atas dapat dilihat hasil belajar siswa pada ranah afektif pada setiap pertemuan berbeda. Perbedaan tersebut terjadi karena ada perbedaan perlakuan di setiap kegiatan pembelajaran.

Selain penilaian pada ranah afektif, juga dilakukan penilaian pada ranah kognitif dan psikomotor. Ranah kognitif dan psikomor dinilai dengan penilaian proyek dan penilaian produk. Penilaian proyek dilaksanakan selama materi optika geometri. Tugas proyek dilaksanakan selama empat pertemuan dalam watu satu bulan. Penilaian proyek adalah penilaian terhadap tugas yang mengandung investigasi dan harus diselesaikan dalam periode/waktu tertentu (Imas dan Berlin : 63). Instrumen penilaian disesuaikan dengan Permendikbud 104 Tahun 2014 yaitu penilaian proyek dilakukan mulai dari perencanaan, pelaksanaan, sampai pelaporan. Kompetensi keterampilan dinilai dengan membandingkan data yang diperoleh dengan rubrik penilaian 
proyek kemudian dijumlah dan dirata-rata. Dari hasil analisis diperoleh nilai rata-rata 3.66 dengan predikat sangat baik.

Pada tahap perancanaan siswa sangat aktif dalam berdiskusi dan mencari sumber referensi. Peran guru menjadi lebih sedikit, namun bukan berarti kemampuan guru menjadi berkurang tetapi peran guru lebih kearah pendamping dan fasilitator. Seperti pendapat Ngalimun (2012: 191) dalam pembelajaran berbasis proyek, guru atau instruktur tidak lebih aktif dan melatih secara langsung, akan tetapi instruktur menjadi pendamping, fasilitator, dan memahami pikiran belajar. Pada tahap pelaksanaan siswa mengerjakan teleskop sederhana tanpa dibantu oleh guru. Ada beberapa kesulitan yang dialami oleh siswa. Kesulitan tersebut adalah mencari fokus lensa yang dibeli. Guru memandu siswa untuk dapat menentukan fokus lensa dengan demonstrasi. Dari kegiatan tersebut siswa dapat membangun pengetahuanya dari pengalaman nyata. Seperti yang diungkapkan oleh Liu (2007) yaitu model pembelajaran berbasis proyek merupakan model pembelajaran yang mengacu pada filosofis konstruktivisme, yang menyatakan bahwa pengetahuan merupakan hasil konstruksi kognitif melalui suatu aktivitas siswa, sehingga siswa dapat mengkonstruksi pengetahuannya sendiri dan bermakna melalui pengalaman yang nyata. Pada akhir materi optika geometri laporan proyek dikumpulkan kemudian dinilai oleh guru. Seperti yang diungkapkan oleh Istarani (2011: 156) yaitu model pembelajaran berbasis proyek merupakan pembelajaran yang dapat meningkatkan kreativitas dan memotivasi siswa lebih aktif dalam menulis.

Selain penilaian proyek, penilaian pada ranah kognitif dan psikomotor dilakukan dengan penilaian produk. Penilaian produk mirip dengan penilaian proyek. Perbedaanya adalah pada tahap akhir penilaian proyek yang dinilai adalah laporan sedangkan pada tahap akhir penilaian produk adalah hasil produk. Seperti yang diungkapkan oleh Kamdi (2008) yaitu fokus dari model pembelajaran berbasis proyek adalah pada konsep-konsep dan prinsipprinsip utama dari suatu disiplin, melibatkan siswa dalam kegiatan pemecahan masalah dan tugas-tugas bermakna lainya, memberi peluang siswa bekerja secara otonom mengkonstruk belajar mereka sendiri, dan puncaknya menghasilkan produk karya siswa. Produk yang dibuat berupa teleskop sederhana dan dibuat sendiri oleh siswa. Penilaian produk adalah penilaian terhadap proses pembuatan dan kualitas suatu produk yang dihasilkan oleh siswa (Kunandar : 306). Instrumen penilaian produk mengacu pada Permendikbud 104 Tahun 2014 meliputi tahap persiapan, pembuatan produk dan penilaian produk. Penilaian dilakukan dengan membandingkan data dengan rubrik peniaian produk. Dari hasil analisi diperoleh nilai produk 3.50 dengan predikat sangat baik.

Pada tahap perancanaan siswa sangat aktif dalam berdiskusi dan mencari sumber referensi. Peran guru menjadi lebih sedikit, namun bukan berarti kemampuan guru menjadi berkurang tetapi peran guru lebih kearah pendamping dan fasilitator. Seperti pendapat Ngalimun (2012: 191) dalam pembelajaran berbasis proyek, guru atau instruktur tidak lebih aktif dan 
melatih secara langsung, akan tetapi instruktur menjadi pendamping, fasilitator, dan memahami pikiran belajar. Pada tahap pelaksanaan siswa mengerjakan teleskop sederhana tanpa dibantu oleh guru. Ada beberapa kesulitan yang dialami oleh siswa. Kesulitan tersebut adalah mencari fokus lensa yang dibeli. Guru memandu siswa untuk dapat menentukan fokus lensa dengan demonstrasi. Dari kegiatan tersebut siswa dapat membangun pengetahuanya dari pengalaman nyata. Seperti yang diungkapkan oleh Liu (2007) yaitu model pembelajaran berbasis proyek merupakan model pembelajaran yang mengacu pada filosofis konstruktivisme, yang menyatakan bahwa pengetahuan merupakan hasil konstruksi kognitif melalui suatu aktivitas siswa, sehingga siswa dapat mengkonstruksi pengetahuannya sendiri dan bermakna melalui pengalaman yang nyata. Pada akhir materi optika geometri siswa mengumpulkan teleskop sederhana.

\subsubsection{Implemantasi Penilaian Autentik pada Pembelajaran Berbasis Proyek}

Hasil obeservasi proses penilaian sikap siswa yang dilakukan selama empat pertemuan menunjukkan peningkatan proses pelaksanaan penilaian sikap. Pada pertemuan pertama persentase keterlaksanaan proses penilaian mencapai $60 \%$. Pada pertemuan selanjutnya mengalami peningatan yaitu $70 \%$ pada pertemuan kedua, $90 \%$ pada pertemuan ketiga dan $90 \%$ pada pertemuan keempat. Hal ini terjadi karena guru masih belum terbiasa menggunakan penilaian autentik. Selain itu jumlah siswa yang banyak yaitu berjumlah tiga puluh enam membuat guru sulit untuk memantau dan menilai siswa. Namun pada pertemuan selanjutnya mengalami peningkatan karena guru sudah mulai terbiasa menggunakan penilaian autentik. Seperti yang diungkapkan oleh Ismet Basuki dan Hariyanto (2014) kelemahan penilaian autentik adalah dapat bersifat tidak praktis untuk kelas yang berisi banyak siswa. Proses penilaian sikap yang dilakukan guru sudah dalam kategori sangat baik pada pertemuan keempat yaitu dengan persentase keterlaksanaan proses penilaian 90\%. Implemetasi penilaian sikap pada pembelajaran berbasis proyek sudah sangat baik dan sesuai dengan prosedur yang ditetapkan dalam Permendikbud No. 104 Tahun 2014.

Hasil observasi proses pelaksanaan penilain proyek yang dilakukan selama materi optika geometri menunjukkan persentase keterlaksanan proses penilaian proyek sebesar 90\% dengan kategori sangat baik. Aspek yang tidak dilakukan oleh guru adalah guru memantau kemajuan tugas proyek siswa. Hal tersebut terjadi karena guru hanya memantau pekerjaan siswa di sekolah saja. Guru tidak memantau pekerjaan siswa di luar sekolah dan diluar jam sekolah. Seperti yang diungkapkan oleh Ismet Basuki dan Hariyanto (2014) kelemahan penilaian autentik adalah memerlukan waktu yang intensif untuk mengelola, mamantau, dan melakukan koordinasi. Ada beberapa keuntungan yang diperoleh dengan penerapan penilaian proyek dalam kegiatan pembelajaran. Siswa dapat bekerja sama dalam proses pembuatan teleskop sederhana. Seperti yang diungkapkan oleh Ismet Basuki dan Hariyanto (2014) kelebiahan 
penilaian autentik adalah mendorong kerja kolaboratif. Keuntungan yang lain adalah siswa dapat menerapakan pengatahuan dan keterampilannya dalam bentuk alat yang berupa teleskop sederhana. Seperti yang diungkapkan oleh Ismet Basuki dan Hariyanto (2014) kelebihan penilaian autentik adalah merefleksikan keterampilan dan pengetahuan di dunia nyata. Proses penilaian proyek yang dilakukan guru sudah dalam kategori sangat baik yaitu dengan persentase keterlaksanaan proses penilaian 90\%. Implemetasi penilaian proyek pada pembelajaran berbasis proyek sudah sangat baik dan sesuai dengan prosedur yang ditetapkan dalam Permendikbud No. 104 Tahun 2014.

Hasil observasi proses pelaksanaan penilaian produk yang dilakukan selama materi optika geometri menunjukkan persentase keterlaksanan proses penilaian proyek sebesar 90\% dengan kategori sangat baik. Aspek yang tidak dilakukan oleh guru adalah guru memantau kemajuan pekerjaan siswa. Hal tersebut terjadi karena guru hanya memantau pekerjaan siswa di sekolah saja. Guru tidak memantau pekerjaan siswa di luar sekolah dan diluar jam sekolah. Seperti yang diungkapkan oleh Ismet Basuki dan Hariyanto (2014) kelemahan penilaian autentik adalah memerlukan waktu yang intensif untuk mengelola, mamantau, dan melakukan koordinasi. Ada beberapa keuntungan yang diperoleh dengan penerapan penilaian produk dalam kegiatan pembelajaran. Siswa dapat bekerja sama dalam proses pembuatan teleskop sederhana. Seperti yang diungkapkan oleh Ismet Basuki dan Hariyanto (2014) kelebihan penilaian autentik adalah mendorong kerja kolaboratif. Keuntungan yang lain adalah siswa dapat menerapakan pengatahuan dan keterampilannya dalam bentuk alat yang berupa teleskop sederhana. Seperti yang diungkapkan oleh Ismet Basuki dan Hariyanto (2014) kelebihan penilaian autentik adalah merefleksikan keterampilan dan pengetahuan di dunia nyata. Proses penilaian produk yang dilakukan guru sudah dalam kategori sangat baik yaitu dengan persentase keterlaksanaan proses penilaian 90\%. Implemetasi penilaian proyek pada pembelajaran berbasis proyek sudah sangat baik dan sesuai dengan prosedur yang ditetapkan dalam Permendikbud No. 104 Tahun 2014.

\subsubsection{Respon Siswa Terhadap Penilaian Autentik}

Dari hasil wawancara diperoleh jawaban dari siswa. Ada jawaban yang berbeda, namun secara keseluruhan jawaban mareka sama. Respon yang paling pertama ditunjukkan siswa adalah siswa menjadi lebih semangat dan lebih bersungguh dalam belajar. Hal ini ditunjukkan dari tanggapan siswa yang mengatakan kecewa apabila hasil karyanya tidak dinilai. Dari pernyataan menunjukkan bahwa adanya penilaian autentik membuat siswa menjadi lebih bersemangat dan bersungguh-sungguh. Respon lain adalah sikap tanggung jawab. Sikap ini mucul ketika siswa benar-benar membuat teleskop sederhana tanpa dibantu orang lain. Teleskop sederhana benar-benar buatan sendiri. Siswa tidak mau membeli atau meminta dibuatkan teleskop sederhana oleh orang lain karena ini adalah tanggung jawab siswa. Respon yang lain adalah sikap disiplin, sikap ini muncul ketika siswa selalu hadir dalam kegitan pembelajaran dan selalu hadir dalam kerja kelompok. Respon yang lain adalah kemampuan pemecahan masalah. Respon tersebut muncul ketika siswa dapat 
membuat rancangan teleskop sederhana. Masalah yang dialami siswa adalah ingin melihat benda yang berada di tempat jauh dengan jelas. Dengan mencari referensi siswa ingin membuat teleskop sederhana untuk memecahakan permasalahan tersebut. Dinilainya kehadiran siswa dalam kegiatan pembelajaran dan kerja kelompok membuat siswa menjadi lebih disiplin. Penilaian autentik memberikan respon yang baik terhadap siswa. Respon yang muncul adalah semangat, lebih bersungguh-sungguh, disipilin, bertanggung jawab dan dapat memecahakan masalah.

\section{Simpulan}

\subsection{Kesimpulan}

Berdasarkan hasil analisis data dan pembahasan, maka kesimpulan yang diperoleh dalam penelitian ini adalah sebagai berikut.

Hasil belajar siswa pada penilaian autentik pada pembelajaran berbasis proyek materi optika geometri kelas X di SMAN 4 Malang dapat dideskripsikan dengan menggunakan penilaian sikap, penilaian proyek dan penilaian produk. Pada ranah afektif sikap siswa mengalami penurunan pada pertemuan kedua dan mengalami kenaikan pada pertemuan ketiga dan keempat. Hasil belajar siswa pada ranah kognitif dan psikomotor berupa kemampuan menghasilkan produk, dapat menyusun laporan proyek, membangun sendiri pengetahuannya dan dapat menerapkan pengetahuannya dalam kehidupan nyata.

4.1.1.Implementasi penilaian autentik untuk ranah sikap pada pembelajaran berbasis proyek kelas X di SMAN 4 Malang dapat dideskripsikan dengan menggunakan lembar observasi penilaian sikap. Persentase proses penilaian sikap mengalami kenaikan dari 60\% dengan kategori cukup pada pertemuan pertama, naik menjadi 90\% dengan kategori sangat baik pada pertemuan ketiga dan keempat.

4.1.2.Implementasi penilaian proyek pada pembelajaran berbasis proyek materi optika geometri kelas X di SMAN 4 Malang dapat dideskripsikan dengan lembar observasi penilaian proyek. Persentase keterlaksanaan penilaian proyek sebesar 90\% dengan kategori sangat baik.

4.1.3. Implementasi penilaian produk pada pembelajaran berbasis proyek materi optika geometri kelas X di SMAN 4 Malang dapat dideskripsikan dengan lembar observasi penilaian proyek. Persentase keterlaksanaan penilaian produk sebesar 90\% dengan kategori sangat baik.

\subsection{Saran}

\subsubsection{Bagi Guru}

Untuk proses penilaian proyek dan produk hendaknya tidak hanya dinilai pada saat disekolah saja. Kerja kelompok diluar jam sekolah maupun diluar sekolah juga dinilai sehingga memperoleh data yang lengkap dan benarbenar dapat menggambarkan kamampuan siswa. Penilaian diluar sekolah dapat dibantu dengan penilaian sistem online sehingga setiap siswa 
mengalami kemajuan pekerjaan dapat di upload dan langsung bisa dinilai oleh guru.

Untuk kelas yang memiliki banyak siswa guru bisa meminta bantuan kepada guru lain untuk membantu menilai siswa. Agar guru dapat fokus memantau dan menilai perkambangan siswa sehingga diperoleh data yang baik dan benar-benar dapat menggambarkan kemampuan siswa yang sebenarnya.

\subsubsection{Bagi Peneliti Lain}

Bagi peneliti lain yang ingin melaksanakan penelitian tentang penilaian autentik dengan kelas yang memiliki banyak siswa hendaknya tidak dilakukan sendirian. Hal tersebut dilakukan agar peneliti dapat fokus mengamati siswa sehingga mendapat data yang baik dan dapat menggambarkan kampuan siswa yang sebenarnya.

\section{Daftar Rujukan}

Gerungan, W. A. (1966). Psychologi sosial. Bandung: PT Eresco.

Hariyanto, I. B. (2014). Asesmen Pembelajaran. Bandung: PT. Remaja Rosdakarya.

Istarani. (2012). 58 Model Pembelajaran Inovatif. Medan: Media Persada.

Kamdi, W. (2007). Pembelajaran berbasis proyek: model potensial untuk peningkatan mutu pembelajaran. Jurnal Gentengkali, Malang.

Kunandar, K. (2013). Penilaian autentik (Penilaian hasil belajar peserta didik berdasarkan Kurikulum 2013). Jakarta: Rajawali Pers.

Kurniasih, I., \& Sani, B. (2014). Implementasi kurikulum 2013: konsep \& penerapan. Kata Pena.

Liu, W. C. (2007). Project-Based Learning And Students' Motivation. Tersedia Pada: Http://Www.Google.Co.Id/Project-Based-Learning-Journalfiletype:Pdf. Diakses Pada Tanggal 21 September 2009.

Murdilarto. (2013). Pembelajaran Terpadu. Jakarta: Amisco.

Ngalimun. (2013). Strategi dan Model Pembelajaran. Banjarmasin: Aswaja Presindo. 